\section{Growth and Development of Basil Species in Response to Temperature}

\author{
Kellie J. Walters and Christopher J. Currey \\ Department of Horticulture, Iowa State University, 106 Horticulture Hall, \\ Ames, IA 50011
}

Additional index words. average daily temperature, Ocimum basilicum, O. $\times$ citriodorum, $O$. tenuiflorum

Abstract. Basil (Ocimum sp.) is the most popular fresh culinary herb, but the effects of air
temperature on growth and development of basil have not been well characterized. Our
objective was to quantify the effects of air temperature on growth and development of
three basil species. Seedlings of sweet basil $(O c i m u m$ basilicum 'Nufar'), holy basil $(O$.
tenuiflorum), and lemon basil $(O$. $\times$ citriodorum 'Lime' and $O$. basilicum 'Sweet Dani')
were placed in five different growth chambers with target air temperatures of $11,17,23$,
29 , or $35{ }^{\circ} \mathrm{C}$. After 3 weeks, chlorophyll fluorescence $\left(F_{v} / F_{m}\right)$, plant height, node and
branch number, fresh and dry weight, and flowering data were recorded. For all species,
$F_{v} / F_{m}$ increased as temperature increased to 17 or $23^{\circ} \mathrm{C}$, then plateaued, whereas height
increased with temperature to 23 or $29{ }^{\circ} \mathrm{C}$. Also, the percentage of plants with flowers or
flower buds increased with temperature to 17 or $23{ }^{\circ} \mathrm{C}$ for all species, with the exception
of sweet basil, of which all plants were vegetative and node appearance rate was
calculated. Sweet basil node appearance increased from 0.03 to 0.30 node/day as the
temperature increased from 11 to $29{ }^{\circ} \mathrm{C}$. Fresh weight gain increased with increasing
temperature to $29{ }^{\circ} \mathrm{C}$, but then decreased at $35{ }^{\circ} \mathrm{C}$. Data from plants grown within the
linear air temperature range were used to develop models for calculating the base
temperature $\left(\mathrm{T}_{\mathrm{b}}\right)$ and predicting growth in response to air temperature. These models
can be applied by commercial producers to schedule crops and predict yields.

Basil (Ocimum sp.) is a commonly cultivated herb with $\approx 64$ species identified (Tucker and DeBaggio, 2009). Although basil is used in several ways, including for essential oil production, as an ornamental plant in landscapes, and as a cut flower, it is used most popularly as a culinary herb (Dole and Wilkins, 2005; Morales and Simon, 1996; Morgan, 2005; Simon et al., 1999; Wogiatzi et al., 2011). Culinary basil is commonly grown outdoors, but in colder climates, year-round hydroponic and potted production in greenhouses are used (Resh, 2013; Walters and Currey, 2015). optimize production time, thus maximizing efficiency and allowing producers to grow plants for specific market dates. Several factors influence the growth and development of plants, and the primary determinant of plant development is temperature (Lopez and Runkle, 2004; Moccaldi and Runkle,

Received for publication 12 Feb. 2018. Accepted for publication 13 May 2019.

We gratefully acknowledge Brianna Vest and Jacob Smith for assistance in collecting data and cleaning, and Peter Lawlor for greenhouse assistance.

The use of trade names in this publication does not imply endorsement by Iowa State University of products named nor criticism of similar ones not mentioned.

K.J.W. is a former graduate research assistant.

C.J.C. is an assistant professor.

C.J.C. is the corresponding author. E-mail: ccurrey@ iastate.edu.
Crop scheduling is used in greenhouses to
2007). Temperature is commonly manipulated by producers and is dependent on many factors, including the crop finishing date, desired size and quality, crop production stage, cost of heating systems and fuel, environmental controls, time of year, and

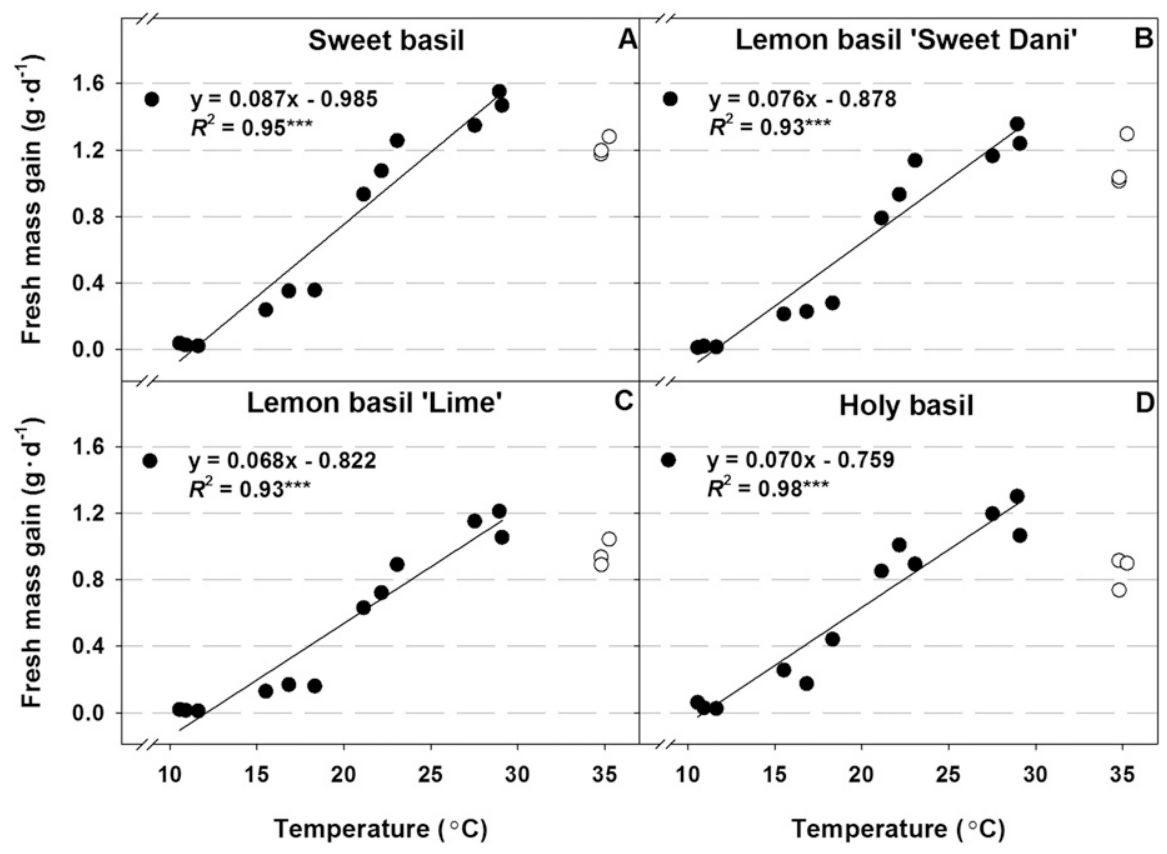
(B) lemon basil 'Sweet Dani' (O. basilicum), (C) lemon basil 'Lime' (O. × citriodorum), and (D) holy basil $(O$. tenuiflorum). Data were collected 3 weeks after transplanting. Each symbol represents the mean of 10 plants in one growth chamber. Data at $\approx 35^{\circ} \mathrm{C}$ were deemed superoptimal and therefore were not included in the regression analysis. ${ }^{* * *}$ Significant at $P \leq 0.001$.
Fig. 1. Influence of air temperature on fresh weight gain of (A) sweet basil (Ocimum basilicum 'Nufar'),

greenhouse type and location. Although greenhouse temperatures fluctuate throughout the day, plants are able to integrate the temperature and, thus, average daily temperature (ADT) is used to describe the effects of temperature on plants. The ADT is the average temperature during a $24-\mathrm{h}$ period and it primarily controls the rate of plant development (Blanchard and Runkle, 2011). $\mathrm{T}_{\mathrm{b}}$ is the temperature less than which plant development ceases. As temperatures increase above $T_{b}$, the rate of development increases to a maximum value at the optimal temperature $\left(\mathrm{T}_{\mathrm{opt}}\right)$. As temperatures increase to more than $\mathrm{T}_{\text {opt }}$, the rate of development decreases until a maximum temperature $\left(\mathrm{T}_{\max }\right)$ is reached, greater than which plants stop developing and may die (Roberts and Summerfield, 1987). Although plant

Table 1. Average $(m e a n \pm S D)$ air temperature for basil grown at five different air temperatures in environmental growth chambers for 3 weeks.

\begin{tabular}{lcc}
\hline Replication & Target temp $\left({ }^{\circ} \mathrm{C}\right)$ & Actual temp $\left({ }^{\circ} \mathrm{C}\right)$ \\
\hline 1 & 11 & $11.6 \pm 0.6$ \\
& 17 & $18.3 \pm 1.7$ \\
& 23 & $21.1 \pm 0.9$ \\
& 29 & $27.5 \pm 1.7$ \\
2 & 35 & $34.8 \pm 2.5$ \\
& 11 & $10.6 \pm 1.8$ \\
& 17 & $15.5 \pm 2.2$ \\
3 & 23 & $22.2 \pm 1.7$ \\
& 29 & $28.9 \pm 1.6$ \\
& 35 & $35.3 \pm 1.8$ \\
& 11 & $10.9 \pm 1.0$ \\
& 17 & $16.8 \pm 0.6$ \\
& 23 & $23.1 \pm 0.6$ \\
& 29 & $29.1 \pm 0.6$ \\
& 35 & $34.8 \pm 0.7$ \\
\hline
\end{tabular}

HortScience Vol. 54(11) November 2019 


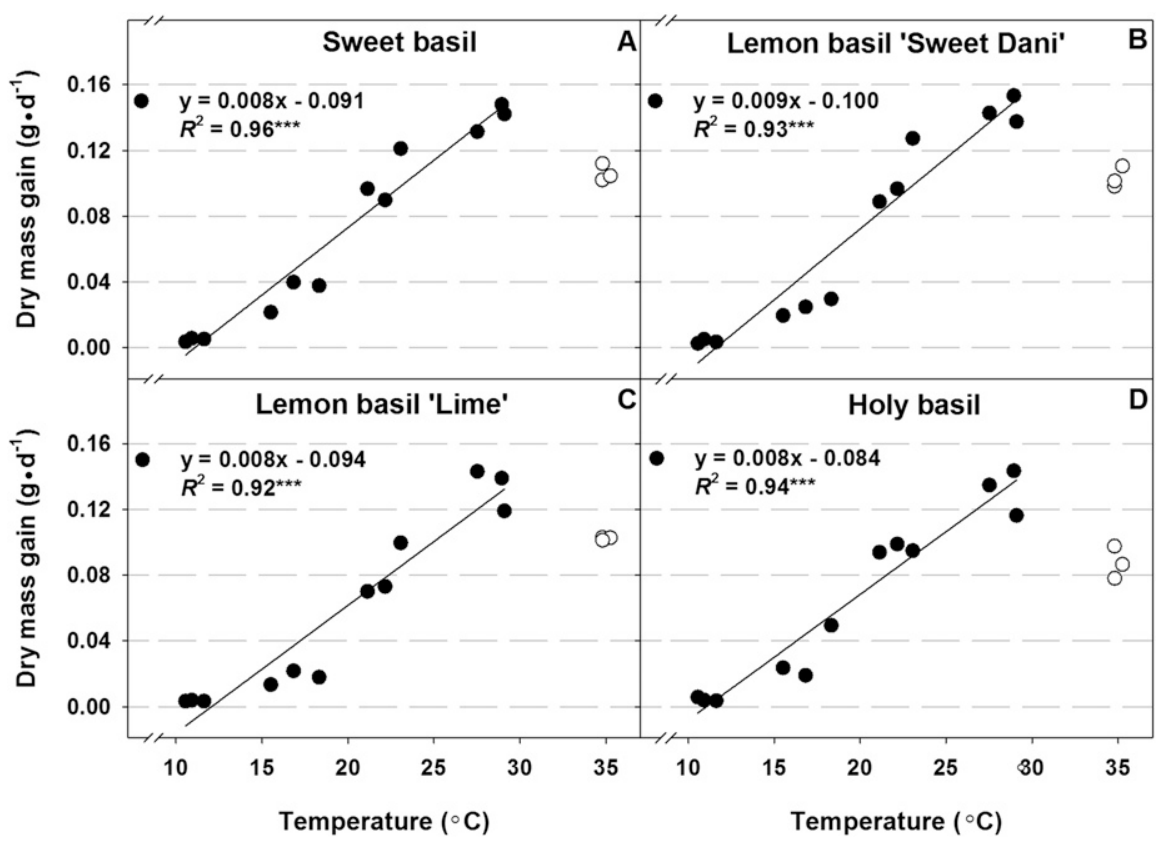

Fig. 2. Influence of air temperature on dry weight gain of (A) sweet basil (Ocimum basilicum 'Nufar'), (B) lemon basil 'Sweet Dani' (O. basilicum), (C) lemon basil 'Lime' $(O$. ×citriodorum), and (D) holy basil (O. tenuiflorum). Data were collected 3 weeks after transplanting. Each symbol represents the mean of 10 plants in one growth chamber. Data at $\approx 35^{\circ} \mathrm{C}$ were deemed superoptimal and therefore were not included in the regression analysis. ***Significant at $P \leq 0.001$.

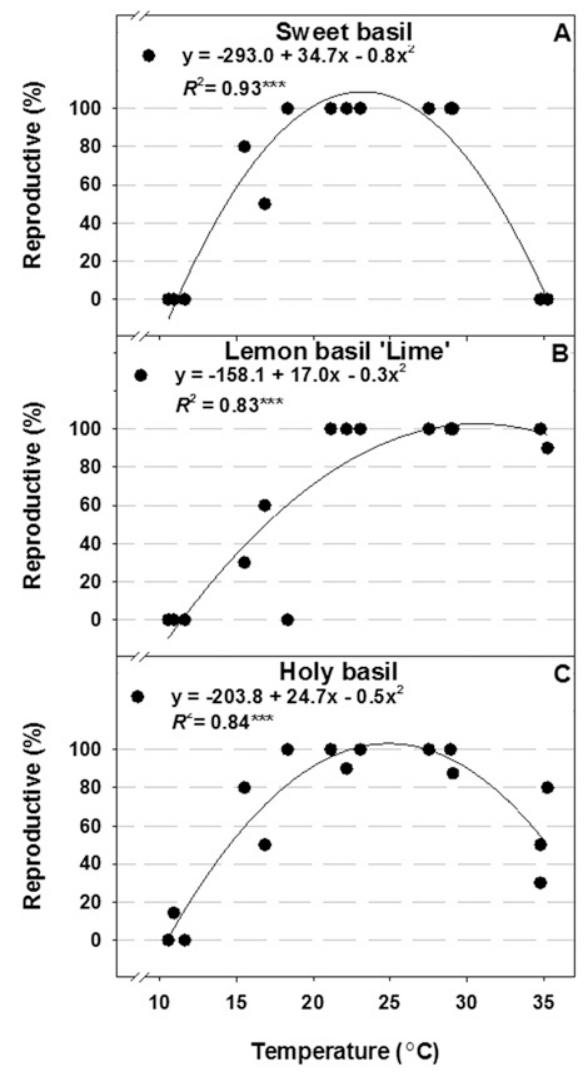

Fig. 3. Influence of air temperature on the percentage of reproductive plants (visible buds or flowers) of (A) lemon basil 'Sweet Dani' (Ocimum basilicum), (B) lemon basil 'Lime' $(O$. $\times$ citriodorum $)$, and $(\mathbf{C})$ holy basil (O. tenuiflorum). Data were collected 3 weeks after transplanting. Each symbol represents the mean of 10 plants in one growth chamber. ${ }^{* * *}$ Significant at $P \leq 0.001$.

\section{Materials and Methods}

Plant material and propagation. Seeds of sweet basil (O. basilicum 'Nufar'), holy basil (O. tenuiflorum), and lemon basil (O. $\times$ citriodorum 'Lime' and $O$. basilicum 'Sweet Dani') were sown individually in 288-cell plug trays filled with a soilless peat-based germination substrate (Farfard Super Fine Germinating Mix; Sun Gro Horticulture, Agawam, MA). Plug trays were placed in an environmental growth chamber (E-41L; Percival Scientific Inc., Perry, IA) with an ADT of $24.1 \pm 0.5^{\circ} \mathrm{C}$ measured every $15 \mathrm{~s}$ with a naturally aspirated temperature sensor (TMC1-HD; Onset Computer Corporation, Bourne, MA) in a solar radiation shield (RS3; Onset Computer Corporation).

A photosynthetic photon flux density $(P P F D)$ of $339 \pm 17 \mu \mathrm{mol} \cdot \mathrm{m}^{-2} \cdot \mathrm{s}^{-1}$ was provided at plant height by fluorescent lamps for $16 \mathrm{~h} / \mathrm{d}$ and was measured every $15 \mathrm{~s}$ with an amplified quantum sensor (SQ-222; Apogee Instruments, Logan, UT). Light intensity and air temperature were logged every $15 \mathrm{~min}$ by a data logger (Hobo U12, Onset Computer Corporation). Seedlings were irrigated as needed with deionized water until radicle emergence, then were supplemented with $100 \mathrm{ppm}$ nitrogen $(\mathrm{N})$ from a water soluble fertilizer $(15 \mathrm{~N}-2.25 \mathrm{P}-12.6 \mathrm{~K}$; Peters Excel CalMag Grower; Everris International B.V., Geldermalsen, The Netherlands).

Air temperature treatments. After 3 $\mathrm{T}_{\max }$ are nonlinear, growth and development between $T_{b}$ and $T_{\text {opt }}$ is not, and it is referred to as the linear range. Temperature models have been developed to improve floriculture crop scheduling and production (Fisher et al., 1996; Kaczperski et al., 1991; Karlsson and Heins, 1992; Lopez and Runkle, 2004; Moccaldi and Runkle, 2007; Torres and Lopez, 2011).

Marketing and production of containerized or hydroponically grown basil are not dependent on flowering; rather, basil is sold when plants attain sufficient weight or size. Researchers have modeled growth of commonly produced leafy green crops such as lettuce (Lactuca sativa L.; Scaife, 1973; Seginer et al., 1991; Thompson et al., 1998). However, predictive models for basil, the most popular culinary herb genera produced in greenhouses and controlled environments (Morgan, 2005), are lacking. Although Chang et al. (2005) evaluated the growth of sweet basil at different temperatures, the study evaluated three temperatures only, which was insufficient to model growth. Mortensen (2014) grew sweet basil at constant air temperatures from 18 to $26{ }^{\circ} \mathrm{C}$. However, with no supraoptimal air temperatures, $\mathrm{T}_{\mathrm{opt}}$ could not be determined, nor was $T_{b}$ or the slope of the linear range calculated. The objective of this study was to quantify the effect of temperature on growth and development of basil species and to develop models for predicting plant growth in response to air temperature, which can be useful to predict growth, schedule crops, and conduct cost-benefit analyses. weeks, seedlings were transplanted into 11.4-cm-diameter containers (volume, 655 $\mathrm{mL}$; ITML, Middlefield, $\mathrm{OH}$ ) filled with a commercial soilless substrate comprised of 3 canadian sphagnum peatmoss: 1 perlite (by volume) amended with dolomitic limestone, starter charge, and a surfactant (Sunshine LC1, Sun Gro Horticulture). Ten plants of each cultivar were placed in five growth chambers (E-41L, Percival Scientific Inc.) with a target ADT of $11,17,23,29$, or $35^{\circ} \mathrm{C}$. Within each chamber, plants were distributed over two shelves within each growth chamber on $17.5-\mathrm{cm}$ centers on each shelf. Actual air temperatures are reported in Table 1 . A $P P F D$ of $366 \pm 14$ (for 17 to $35^{\circ} \mathrm{C}$ treatments) or $268 \pm 19$ (for $11{ }^{\circ} \mathrm{C}$ treatment) $\mu \mathrm{mol} \cdot \mathrm{m}^{-2} \cdot \mathrm{s}^{-1}$ was provided by fluorescent lamps for $16 \mathrm{~h} / \mathrm{d}(0600-2200 \mathrm{HR})$, resulting in daily light integrals (DLIs) of 21.1 and $15.4 \mathrm{~mol} \cdot \mathrm{m}^{-2} \cdot \mathrm{d}^{-1}$, respectively. The light intensity decreased in the lowest temperature treatment because of the diminished output of fluorescent lamps as a result of the low air temperature (Bleeker and Veenstra, 1990). Plants were fertilized weekly with $200 \mathrm{ppm} \mathrm{N}$ from the same fertilizer as described earlier and irrigated as needed with deionized water.

Data collection and calculation. The height, and node and branch numbers $(>2.5$ $\mathrm{cm}$ ) of 10 seedlings of each cultivar were recorded at the time of transplant. In addition, seedlings were severed at the substrate surface, weighed immediately on a balance, and shoot fresh weight was recorded. Shoots were placed in a forced-air drier maintained at $67^{\circ} \mathrm{C}$ for $3 \mathrm{~d}$, then weighed; dry weight was 


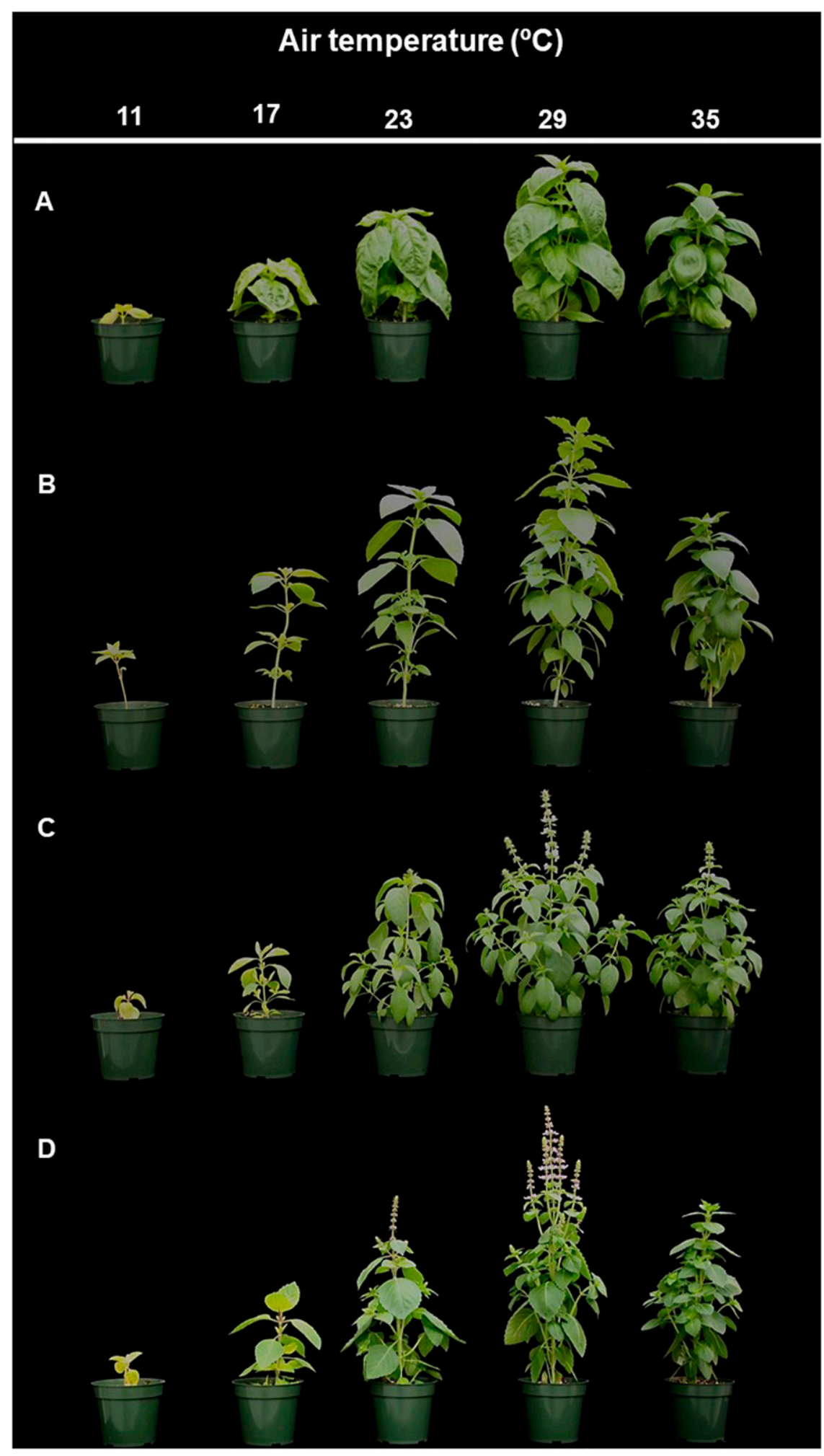

Fig. 4. (A) Sweet basil (O. basilicum 'Nufar'), (B) lemon basil 'Sweet Dani' (O. basilicum), (C) lemon basil 'Lime' (O. Xcitriodorum), and (D) holy basil (O. tenuiflorum) plants grown at different air temperatures for 3 weeks.

recorded. Three weeks after placing plants into temperature treatments, chlorophyll fluorescence of five plants per treatment per replication was measured on the adaxial surface of the most fully expanded leaf using a chlorophyll fluorescence meter (Plant Efficiency Analyzer; Hansatech Instruments
Ltd., Norfolk, UK). Using the manufacturer's clip, leaves were dark-acclimated for $15 \mathrm{~min}$ before measurements were taken. Fluorescence was measured by opening a shutter in the dark-acclimating clip and exposing the leaf to red light (peak wavelength of $650 \mathrm{~nm}$ at $\left.3000 \mu \mathrm{mol} \cdot \mathrm{m}^{-2} \cdot \mathrm{s}^{-1}\right)$ for $5 \mathrm{~s}$ to saturate photosystem II (PSII). Chlorophyll fluorescence was expressed as $F_{v} / F_{m}$. Then, plant height from the substrate surface to the top vegetative node (excluding the inflorescence, if present), number of branches $(>2.5 \mathrm{~cm})$, and number of plants flowering or with a visible bud were recorded for 10 plants per treatment per replication, and the percentage of reproductive plants was calculated. The number of nodes with expanded leaves was counted, and node appearance rate was calculated (node number/time to harvest) on nonreproductive species. Plants were then severed at the substrate surface, weighed immediately, and shoot fresh weight (including flowers and flower buds, if present) was recorded. Shoots were then placed in a forced-air drier maintained at $67^{\circ} \mathrm{C}$ for $3 \mathrm{~d}$, then weighed; dry weight was recorded. Fresh and dry weight gain was obtained by subtracting the initial weight of representative seedlings from the final weight and dividing the increase in fresh and dry weight by time to harvest ( 3 weeks).

Experimental design and statistical analyses. The experiment was organized in a randomized complete block design. The experiment was replicated three times over time and, for each replication in time, there was a single replication (growth chamber) for each temperature with 10 plants of each cultivar per temperature treatment. Data were analyzed using Sigma Plot version 12.3 (Systat Software Inc., San Jose, CA) for regression analyses using one replication (mean of 10 plants) as one data point.

\section{Results}

Sweet basil, lemon basil 'Sweet Dani', lemon basil 'Lime', and holy basil fresh weight gain increased by $1.44,1.22,1.04$, and $1.04 \mathrm{~g} \cdot \mathrm{d}^{-1}$, respectively, as temperature increased from 10.9 to $29.1{ }^{\circ} \mathrm{C}$, then decreased by $0.27,0.20,0.16$, and $0.33 \mathrm{~g} \cdot \mathrm{d}^{-1}$, respectively, as temperature further increased to $34.8{ }^{\circ} \mathrm{C}$ (Fig. 1). Estimated $\mathrm{T}_{\mathrm{b}}$ for fresh mass for these cultivars was 11.3, 11.6, 12.1, and $10.9{ }^{\circ} \mathrm{C}$, respectively. Similarly, dry weight gain of all species increased linearly from $\approx 11$ to $\approx 29^{\circ} \mathrm{C}$, then decreased (Fig. 2). Dry weight gain increased by $0.14,0.13$, 0.12 , and $0.11 \mathrm{~g} \cdot \mathrm{d}^{-1}$ as air temperature increased from 10.9 to $29.1{ }^{\circ} \mathrm{C}$ for sweet basil, lemon basil 'Sweet Dani', lemon basil 'Lime', and holy basil, respectively (Fig. 2), then decreased (by $0.03,0.04,0.02$, and 0.04 $\mathrm{g} \cdot \mathrm{d}^{-1}$, respectively) as temperature further increased to $34.8{ }^{\circ} \mathrm{C}$. Estimated $\mathrm{T}_{\mathrm{b}}$ for dry weight gain of sweet basil, lemon basil 'Sweet Dani', lemon basil 'Lime', and holy basil was $11.1,11.6,12.0$, and $11.1^{\circ} \mathrm{C}$, respectively.

The percentage of plants with flowers or flower buds increased from 14\% (holy basil) and $0 \%$ (lemon basil 'Sweet Dani' and 'Lime') at $10.9^{\circ} \mathrm{C}$ to $100 \%$ at $23.1^{\circ} \mathrm{C}$, then the percentages stayed the same or decreased as temperature increased further (Figs. 3 and 4). Sweet basil remained vegetative at every temperature (Fig. 4). The node appearance of 
sweet basil increased from $\approx 11$ to $\approx 29{ }^{\circ} \mathrm{C}$ (for example, 0.27 node/d was observed as air temperature increased from 10.6 to $28.9{ }^{\circ} \mathrm{C}$ ), then decreased as temperature increased to more than $\approx 29{ }^{\circ} \mathrm{C}$ (Fig. 5). The calculated $\mathrm{T}_{\mathrm{b}}$ for node appearance rate was $8.2^{\circ} \mathrm{C}$.

Height increased as temperature increased from $\approx 11$ to $\approx 23{ }^{\circ} \mathrm{C}$ (for lemon basil 'Lime' and holy basil) or to $\approx 29^{\circ} \mathrm{C}$ (for sweet basil and lemon basil 'Sweet Dani'), but then plateaued or decreased as temperature increased further to $\approx 35{ }^{\circ} \mathrm{C}$ (Fig. 6). For example, lemon basil 'Lime' and holy basil height increased by 15.8 and $16.4 \mathrm{~cm}$, respectively, as temperature increased from 10.6 to $22.2{ }^{\circ} \mathrm{C}$. The height of sweet basil and lemon basil 'Sweet Dani' increased by

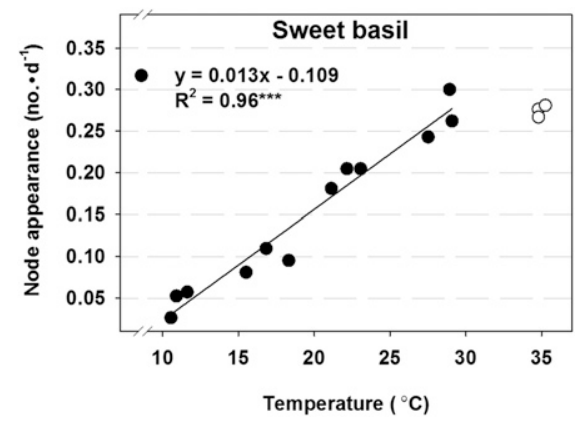

Fig. 5. Influence of air temperature on node appearance of sweet basil (Ocimum basilicum 'Nufar'). Data were collected 3 weeks after transplanting. Each symbol represents the mean of 10 plants in one growth chamber. Data at $\approx 35{ }^{\circ} \mathrm{C}$ were not included in regression equation. $* * *$ Significant at $P \leq 0.001$.
23.4 and $30.7 \mathrm{~cm}$ as temperature increased from 10.6 to $28.9^{\circ} \mathrm{C}$, then decreased by 6.8 and $7.9 \mathrm{~cm}$, respectively, as temperature increased further to $35.3{ }^{\circ} \mathrm{C}$.

At $10.6{ }^{\circ} \mathrm{C}$, sweet basil had internode lengths $1.6 \mathrm{~cm}$ shorter than plants grown at $28.9^{\circ} \mathrm{C}$ (Fig. 7). However, as air temperature increased to $35.3{ }^{\circ} \mathrm{C}$, internode length decreased by $0.7 \mathrm{~cm}$. Internode length of lemon basil 'Lime' and holy basil increased by 1.4 $\mathrm{cm}$ as air temperature increased from 10.6 to $22.2{ }^{\circ} \mathrm{C}$. However, internode length decreased by 0.4 and $0.7 \mathrm{~cm}$ as temperature further increased to $35.3{ }^{\circ} \mathrm{C}$. Lemon basil 'Sweet Dani' internode length decreased from $3.6 \mathrm{~cm}$ to $1.7 \mathrm{~cm}$ as temperature increased from 11.6 to $18.3{ }^{\circ} \mathrm{C}$, then increased to $3.9 \mathrm{~cm}$ at $21.1{ }^{\circ} \mathrm{C}$. As temperature increased further to $34.8{ }^{\circ} \mathrm{C}$, internode length decreased to $2.9 \mathrm{~cm}$.

Sweet basil had no branches when grown at $\approx 11$ to $\approx 17{ }^{\circ} \mathrm{C}$, after which branch number increased by up to 9.3 branches as temperature increased to $\approx 35{ }^{\circ} \mathrm{C}$ (data not shown). As air temperature increased from 11.6 to $27.5{ }^{\circ} \mathrm{C}$, lemon basil 'Sweet Dani' branch number increased from 0 to 11.3 branches. Lemon basil 'Lime' branch number increased from 0 to 15.0 branches as temperature increased from 11.6 to $34.8{ }^{\circ} \mathrm{C}$, whereas holy basil branch number increased from 0 to 11.6 branches as air temperature increased from 11.6 to $21.1^{\circ} \mathrm{C}$, then branch number plateaued.

Sweet basil and lemon basil 'Lime' $F_{v} / F_{m}$ increased from 0.49 to 0.84 and 0.51 to 0.84 , respectively, as air temperature increased from 10.9 to $23.1^{\circ} \mathrm{C}$ (Fig. 8), whereas lemon basil

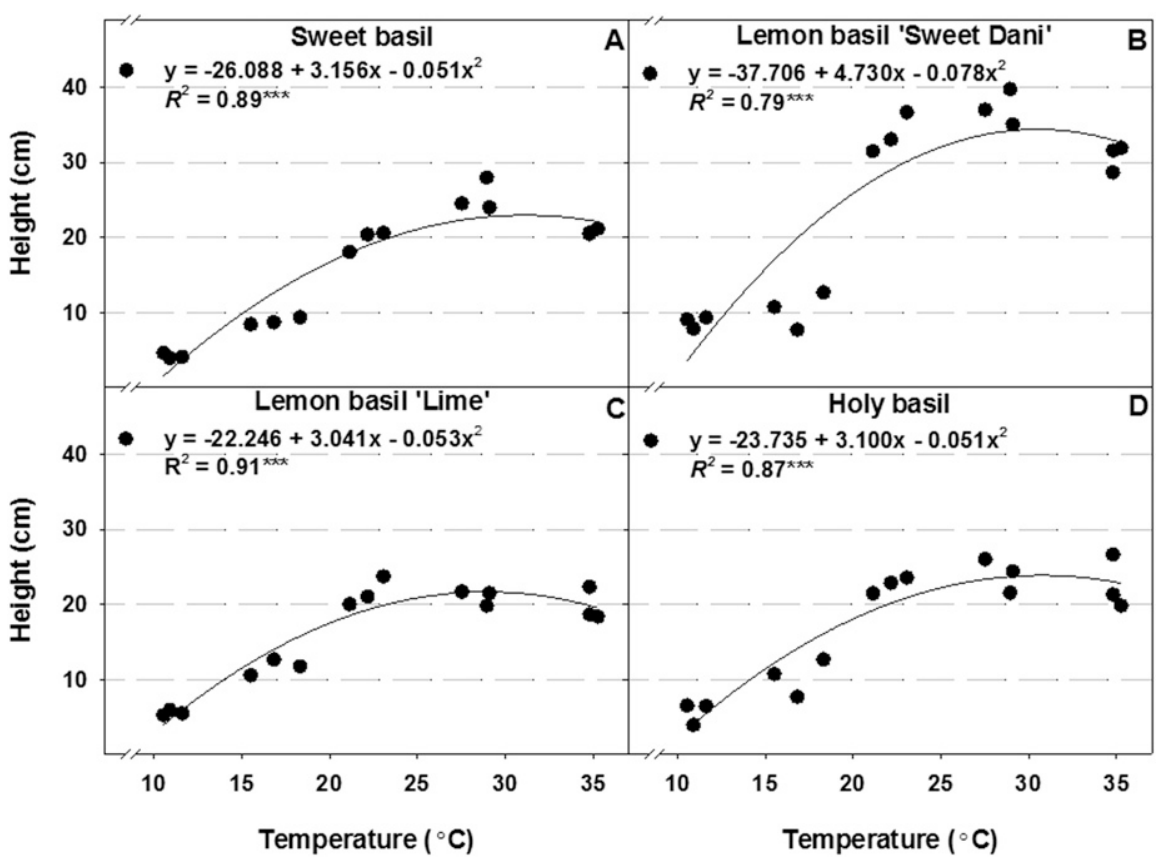

Fig. 6. Influence of air temperature on the height of (A) sweet basil (Ocimum basilicum 'Nufar'), (B) lemon basil 'Sweet Dani' (O. basilicum), (C) lemon basil 'Lime' (O. × citriodorum), and (D) holy basil ( $O$. tenuiflorum). Data were collected 3 weeks after transplanting. Each symbol represents the mean of 10 plants in one growth chamber. $* * *$ Significant at $P \leq 0.001$.
'Sweet Dani' and holy basil $F_{v} / F_{m}$ increased from 0.61 to 0.80 and 0.60 to 0.81 , respectively, as temperature increased from 10.9 to $16.8{ }^{\circ} \mathrm{C}$. After increasing to $\approx 17$ or $\approx 23{ }^{\circ} \mathrm{C}$, $F_{v} / F_{m}$ values for all species plateaued.

\section{Discussion}

The results presented here provide a comprehensive evaluation on the effects of air temperature on growth and development of four basil species. Our sweet basil results have a similar trend as those from Chang et al. (2005) and Mortensen (2014), although they differ in respect to magnitude. In the work by Chang et al. (2005), after 1 week of temperature treatments, the fresh and dry weight of sweet basil increased by $27 \%$ and $29 \%$, respectively, as temperature increased from 15 to $25^{\circ} \mathrm{C}$. Our models showed increases of $272 \%$ and $276 \%$, respectively, after 3 weeks of growth. Mortensen (2014) reported the fresh weight of sweet basil increased by $106 \%$ as temperature increased from 18 to $26{ }^{\circ} \mathrm{C}$, whereas our models predicted a $120 \%, 124 \%, 135 \%$, and $112 \%$ increase in sweet basil, lemon basil 'Sweet Dani', lemon basil 'Lime', and holy basil, respectively, across the same temperature range. In contrast, Chang et al. (2005) found no differences in weight between plants grown at 25 and $30{ }^{\circ} \mathrm{C}$ and, although the air temperatures were different, our results showed a $51 \%$ and $52 \%$ increase in fresh and dry weight of sweet basil, respectively, as temperatures increased from 23 to $29{ }^{\circ} \mathrm{C}$, followed by a decrease as temperature increased to $\approx 35{ }^{\circ} \mathrm{C}$. Similar to our findings, Caliskan et al. (2009) determined relative growth rate of sweet basil increased as temperature increased up to $28{ }^{\circ} \mathrm{C}$, then decreased. However, Caliskan et al. (2009) defined relative growth rate as the growth rate per unit leaf area per day multiplied by the leaf area of the plant divided by its total dry weight, whereas we calculated the fresh and dry weight gain. Chang et al. (2005) found that basil node number increased by $14 \%$ as temperature increased from 15 to $25^{\circ} \mathrm{C}$, with no effect by increasing temperature further to $30{ }^{\circ} \mathrm{C}$. Similarly, in our study, the node appearance rate of sweet basil increased as temperature increased up to $29{ }^{\circ} \mathrm{C}$, then decreased as temperature increased to $35{ }^{\circ} \mathrm{C}$, whereas the predicted increase from 15 to $25{ }^{\circ} \mathrm{C}$ was $151 \%$. Mortensen (2014) highlighted a $125 \%$ increase and Chang et al. (2005) reported a $27 \%$ increase in sweet basil height as temperature increased from 18 to $26{ }^{\circ} \mathrm{C}$ or from 15 to $25{ }^{\circ} \mathrm{C}$, respectively. Similarly, our results predicted an increase in height of $51 \%$ and $114 \%$ as temperature increased from 18 to $26{ }^{\circ} \mathrm{C}$ and from 15 to $25{ }^{\circ} \mathrm{C}$, respectively. When increasing temperature from 25 to $30^{\circ} \mathrm{C}$, Chang et al. (2005) reported no differences in plant height; whereas in our research, as temperature increased from 29 to $35^{\circ} \mathrm{C}$, height decreased.

In our study, increasing temperature up to $\approx 17$ to $\approx 23{ }^{\circ} \mathrm{C}$ increased the number of plants with flowers or buds in 'Sweet Dani' 


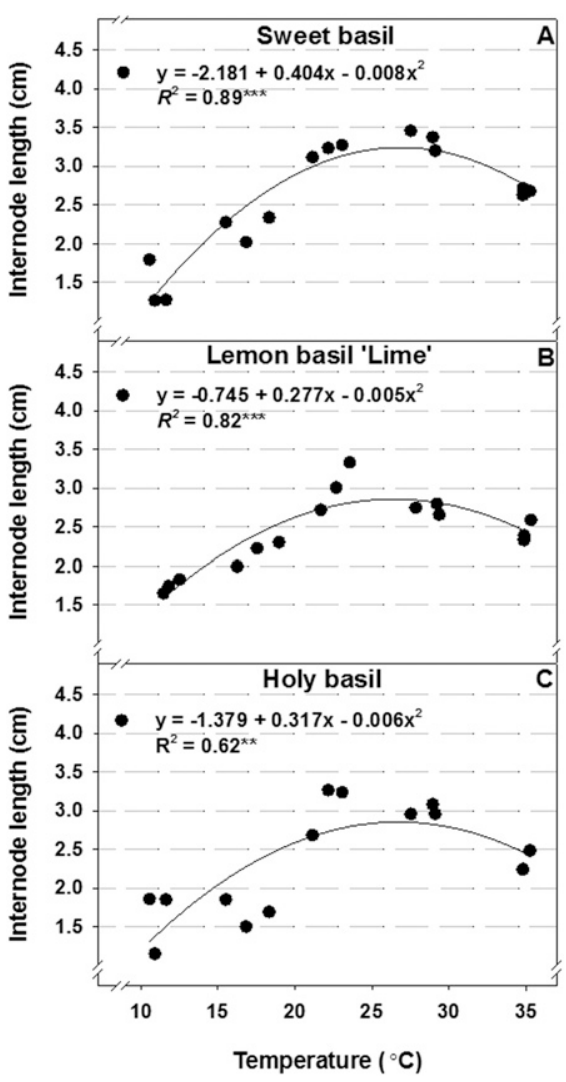

Fig. 7. Influence of temperature on internode length of (A) sweet basil (Ocimum basilicum 'Nufar'), (B) lemon basil 'Lime' ( $O$. $\times$ citriodorum), and (C) holy basil (O. tenuiflorum). Data were collected 3 weeks after transplanting. Each symbol represents the mean of 10 plants in one growth chamber. $* *, * * *$ Significant at $P \leq 0.01$ or 0.001 , respectively.

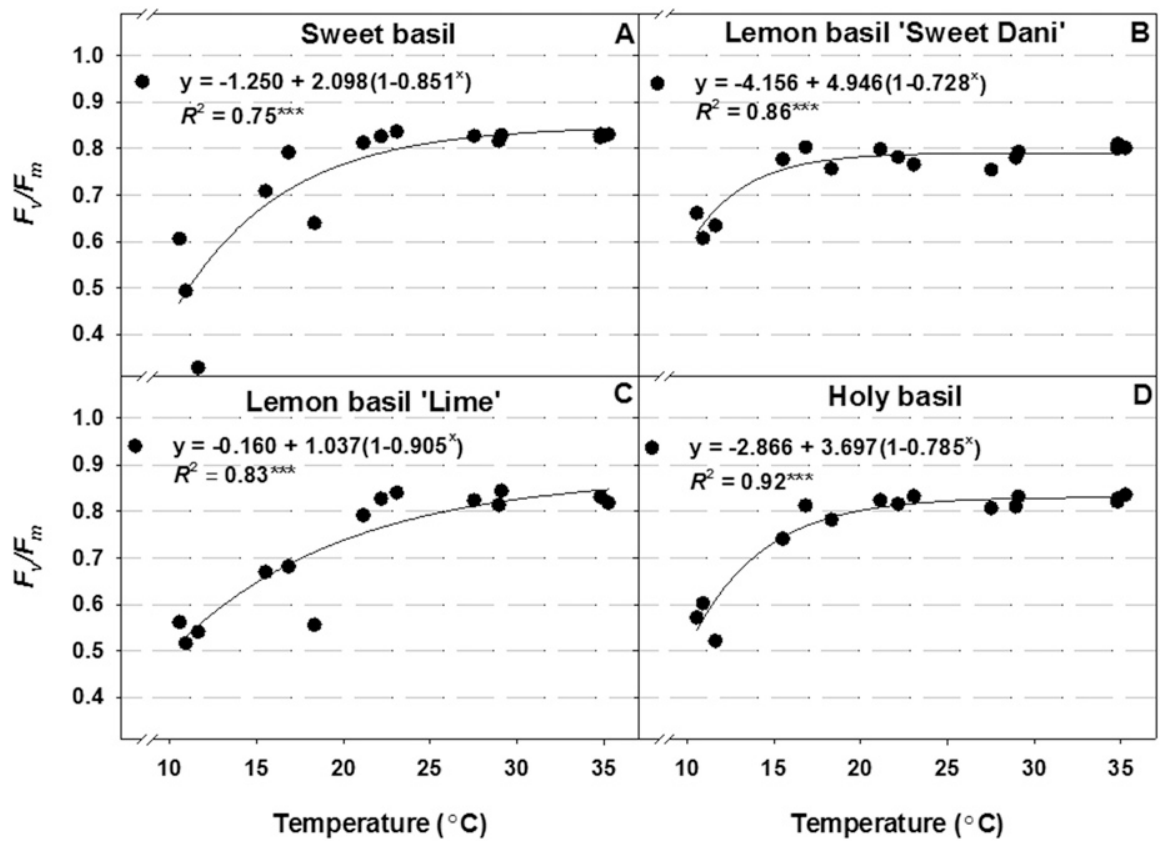

Fig. 8. Influence of temperature on chlorophyll fluorescence $\left(\mathrm{F}_{\mathrm{v}} / \mathrm{F}_{\mathrm{m}}\right)$ of $(\mathbf{A})$ sweet basil (Ocimum basilicum 'Nufar'), (B) lemon basil 'Sweet Dani' (O. basilicum), (C) lemon basil 'Lime' (O. Xcitriodorum), and (D) holy basil (O. tenuiflorum). Data were collected 3 weeks after transplanting. Each symbol represents five plants in one growth chamber. ${ }^{* * *}$ Significant regression at $P \leq 0.001$.
(Maxwell and Johnson, 2000). Our research quantified lower $F_{v} / F_{m}$ values for the basil species and cultivars in this study at $\approx 11$ to $\approx 17{ }^{\circ} \mathrm{C}$ or $\approx 23{ }^{\circ} \mathrm{C}$, but reached nonstressed $F_{v} / F_{m}$ values near 0.8 when temperatures were between $\approx 17{ }^{\circ} \mathrm{C}$ or $\approx 23$ to $\approx 35^{\circ} \mathrm{C}$, depending on the species.

As temperature increases above $T_{b}$, the rate of development increases to $\mathrm{T}_{\mathrm{opt}}$, then decreases until $\mathrm{T}_{\max }$ (Roberts and Summerfield, 1987). Therefore, plants should be grown at temperatures between $\mathrm{T}_{\mathrm{b}}$ and $\mathrm{T}_{\mathrm{opt}}$ $\mathrm{T}_{\text {opt }}$ varies between species. For example, $\mathrm{T}_{\text {opt }}$ for pansy is $21.7^{\circ} \mathrm{C}$, classifying it as a cool-season or heat-sensitive crop (Adams et al., 1997; Blanchard and Runkle, 2011). Alternatively, the warm-season or heattolerant crop hibiscus has a $\mathrm{T}_{\text {opt }}$ of $32{ }^{\circ} \mathrm{C}$ (Karlsson et al., 1991). Based on the air temperatures used in our study, we were unable to identify $\mathrm{T}_{\max }$ and $\mathrm{T}_{\text {opt }}$ for the basil species and cultivars evaluated. However, when reviewing our data, it was clear $T_{\text {opt }}$ for basil is between 29 and $35^{\circ} \mathrm{C}$, classifying it as a warm-season or heat-tolerant crop. Further studies including more temperatures between 29 and $35{ }^{\circ} \mathrm{C}$ and more than $35^{\circ} \mathrm{C}$ would be useful in modeling growth to identify $T_{\text {opt }}$ and $T_{\max }$, respectively.

In addition to classifying the temperature responses of basil species, the data reported herein and the linear models generated from the results can be used to predict growth of sweet, lemon, and holy basil in response to air temperature. This is especially useful for scheduling production or estimating the effects of changes in air temperature. For example, using the model for sweet basil and assuming a marketable shoot is $\approx 22 \mathrm{~g}$, it will take 36,27 , or $22 \mathrm{~d}$ to produce a harvestable shoot at 18,20 , or $22{ }^{\circ} \mathrm{C}$, respectively, when starting from a seedling weighing $\approx 1 \mathrm{~g}$. Producers can then conduct a cost-benefit analysis to determine the most profitable air temperature to grow a sweet basil crop, or predict yields or time to harvest marketable shoots.

The DLI influences growth and development and should be taken into account when using these models. For example, when sweet basil 'Genovese', 'Italian Large Leaf', and 'Nufar' were grown with an ADT of $21^{\circ} \mathrm{C}$, shoot dry weight of a 3-week-old plant increased by $0.77 \mathrm{~g}-\mathrm{a} 467 \%$ increase as DLI increased from to 5.3 to $24.9 \mathrm{~mol} \cdot \mathrm{m}^{-2} \cdot \mathrm{d}^{-1}$ (Chang et al., 2008). Given the slow growth rate of plants grown at $11{ }^{\circ} \mathrm{C}$, we do not believe the lower DLI affected growth appreciably. Additional growth analysis studies would be useful to investigate the interaction of temperature and DLI on growth and development of basil.

\section{Conclusions}

In general, increasing air temperature to $\approx 29{ }^{\circ} \mathrm{C}$ resulted in an increase in fresh and dry weight accumulation, node number, percent of plants with visible flower buds or flowers, plant height, internode length, branch number, and chlorophyll fluorescence 
for all species and cultivars evaluated. Basil is a cold-sensitive, heat-tolerant crop. The linear models developed can be useful in predicting growth of different basil species and cultivars at common greenhouse air temperatures. Although air temperature is usually manipulated by producers, preferred greenhouse air temperature is dependent on many factors, including the crop finishing dates, desired size and quality, crop production stage, cost of heating systems and fuel, environmental controls, time of year, greenhouse type and location, and requirements of other plants grown in the greenhouse. Producers are urged to conduct on-site trials to determine plant growth and development at temperatures under their production practices.

\section{Literature Cited}

Adams, S.R., S. Pearson, and P. Hadley. 1997. The effects of temperature, photoperiod and light integral on the time to flowering of pansy cv. Universal Violet (Viola $\times$ wittrockiana Gams.). Ann. Bot. 80:107-112.

Blanchard, M.G. and E.S. Runkle. 2011. Temperature, p. 67-81. In: J. Nau (ed.). Ball redbook vol 2. Crop production. 18th ed. Ball Publishing, West Chicago, IL.

Bleeker, N. and W. Veenstra. 1990. The performance of four food fluorescent lamps as a function of ambient temperature on $60 \mathrm{~Hz}$ and high frequency ballasts. Annu. Illuminating Eng. Soc. Conf., Paper A. vol. 45.

Caliskan, O., M.S. Odabas, and C. Cirak. 2009. The modeling of the relation among the temperature and light intensity of growth in Ocimum basilicum L. J. Med. Plants Res. 3:965-977.

Chang, X., P.G. Alderson, and C.J. Wright. 2005. Effect of temperature integration on the growth and volatile oil content of basil (Ocimum basilicum L.). J. Hort. Sci. Biotechnol. 80:583-598.

Chang, X., P.G. Alderson, and C.J. Wright. 2008. Solar irradiance level alters the growth of basil
(Ocimum basilicum L.) and its content of volatile oils. Environ. Expt. Bot. 63:216-223.

Dole, J.M. and H.F. Wilkins. 2005. Floriculture: Principles and species. 2nd ed. Prentice Hall, Upper Saddle River, NJ.

Fisher, P.R., J.H. Lieth, and R.D. Heins. 1996. Modeling flower bud elongation in easter lily (Lilium longiflorum Thunb.) in response to temperature. HortScience 31:349-352.

Kaczperski, M.P., W.H. Carlson, and M.G. Karlsson. 1991. Growth and development of Petunia $\times$ hybrids as a function of temperature and irradiance. J. Amer. Soc. Hort. Sci. 116:232-237.

Karlsson, M.G. and R.D. Heins. 1992. Chrysanthemum dry matter partitioning patterns along irradiance and temperature gradients. Can. J. Plant Sci. 72:307-316.

Karlsson, M.G., R.D. Heins, J.O. Gerberick, and M.E. Hackmann. 1991. Temperature driven leaf unfolding rate in Hibiscus rosa-sinensis. Scientia Hort. 45:323-331.

Lopez, R.G. and E.S. Runkle. 2004. The effect of temperature on leaf and flower development and flower longevity of Zygopetalum redvale 'Fire Kiss' orchid. HortScience 39:1630 1634.

Maxwell, K. and G.N. Johnson. 2000. Chlorophyll fluorescence: A practical guide. J. Expt. Bot. 51:659-668.

Moccaldi, L.A. and E.S. Runkle. 2007. Modeling the effects of temperature and photosynthetic daily light integral on growth and flowering of Salvia splendens and Tagetes patula. J. Amer. Soc. Hort. Sci. 132:283-288.

Morales, M.R. and J.E. Simon. 1996. New basil selections with compact inflorescences for the ornamental market, p. 543-546. In: J. Janick (ed.). Progress in new crops. ASHS Press, Arlington, VA.

Morgan, L. 2005. Fresh culinary herb production. Suntec NX Ltd., Tokomaru, New Zealand.

Mortensen, L.M. 2014. The effect of air temperature on growth of eight herb species. Amer. J. Plant Sci. 5:1542-1546.

Resh, H. 2013. Hydroponic food production: A definitive guidebook for the advanced home gardener and commercial hydroponic grower. 7th ed. CRC Press, Boca Raton, FL.

Roberts, E.H. and R.J. Summerfield. 1987. Measurement and prediction of flowering in annual crops, p. 17-50. In: J.G. Atherton (ed.). Manipulation of flowering. Butterworths, London, UK.

Scaife, M.A. 1973. The early relative growth rates of six lettuce cultivars as affected by temperature. Ann. Appl. Biol. 74:119-128.

Seginer, I., G. Shina, L.D. Albright, and L.S. Marsh. 1991. Optimal temperature setpoints for greenhouse lettuce. J. Agr. Eng. Res. 49:209-226.

Simon, J.E., M.R. Morales, W.B. Phippen, R.F. Vieira, and Z. Hao. 1999. Basil: A source of aroma compounds and a popular culinary and ornamental herb, p. 449-505. In: J. Janick (ed.). Perspectives on new crops and new uses. ASHS Press, Arlington, VA.

Thompson, H.C., R.W. Langhans, A.J. Both, and L.D. Albright. 1998. Shoot and root temperature effects on lettuce growth in a floating hydroponic system. J. Amer. Soc. Hort. Sci. 123:361-364.

Torres, A.P. and R.G. Lopez. 2011. Photoperiod and temperature influence flowering responses and morphology of Tecoma stans. HortScience 46:416-419.

Tucker, A.O. and T. DeBaggio. 2009. The encyclopedia of herbs: A comprehensive reference to herbs of flavor and fragrance. Timber Press, Portland, OR.

Walters, K.J. and C.J. Currey. 2015. Hydroponic greenhouse basil production: Comparing systems and cultivars. HortTechnology 25:645-650.

Warner, R.M. and J.E. Erwin. 2006. Prolonged high-temperature exposure differentially reduces growth and flowering of 12 Viola $\times$ wittrockiana Gams. cvs. Scientia Hort. 108:295-302.

Wogiatzi, E., A. Papachatzis, H. Kalorizou, A. Chouliara, and N. Chouliaras. 2011. Evaluation of essential oil yield and chemical components of selected basil cultivars. Biotechnol. Biotechnol. Equip. 25:2525-2527. 